\title{
INTERPRETING FILMS
}





\title{
INTERPRETING FILMS
}

\author{
STUDIES IN THE \\ HISTORICAL RECEPTION OF \\ AMERICAN CINEMA
}

Janet Staiger

PRINCETON UNIVERSITY PRESS PRINCETON, NEW JERSEY 
Copyright (C 1992 by Princeton University Press

Published by Princeton University Press, 41 William Street,

Princeton, New Jersey 08540

In the United Kingdom: Princeton University Press, Chichester, West Sussex

All Rights Reserved

\section{Library of Congress Cataloging-in-Publication Data}

Staiger, Janet.

Interpreting films : studies in the historical reception of

American cinema / Janet Staiger.

p. $\quad \mathrm{cm}$.

Includes bibliographical references and index.

ISBN 0-691-04797-9 - ISBN 0-691-00616-4 (pbk.)

1. Motion pictures-Aesthetics. 2. Reader-response criticism.

3. Motion pictures-United States. I. Title.

PN1995.S6735 1992

791.43'01—dc20 91-22248 CIP

This book has been composed in Linotron Galliard

Princeton University Press books are printed on acid-free paper, and meet the guidelines for permanence and durability of the Committee on Production Guidelines for Book Longevity of the Council on Library Resources

Printed in the United States of America

$\begin{array}{lllllllll}3 & 5 & 7 & 9 & 10 & 8 & 6 & 4 & 2\end{array}$ 
For Peter Staiger and

Iryl and Don Voelte 
